\title{
AN INTERNATIONAL GOLD STANDARD WITHOUT GOLD
}

\author{
Ronald I. McKinnon
}

What can history tell us about the desirability, and feasibility, of maintaining fixed exchange rates between national currencies when capital is highly mobile? The workings of the international gold standard from the late 1870s to August 1914 provide the best example we have. Unlike the Bretton Woods system of pegged exchange rates in the 1950s and 1960s, or the residual controls of today's European Monetary System, no exchange controls impeded gross flows of financial capital. Moreover, net transfers of capital between countries were huge: Large net trade surpluses (deficits) opened and closed continually with no adjustments in nominal exchange rates and, by modern standards, with little change in real exchange rates. World trade grew rapidly.

Nevertheless, fixed exchange rates in general, and the gold standard in particular, remain as unpopular among American economists today as they were with the Populists who almost succeeded in electing William Jennings Bryan president in 1896. From 1873 onward America's acquiescence to the discipline of the gold standard and to British dominance of the international capital market was always somewhat grudging (Hale 1988). Even the formation of the Federal Reserve System in 1913 was an attempt to make American control over domestic money and credit somewhat more independent of international influences.

But this discrediting of fixed exchange rates, and subsequent refusal to bend American monetary policy toward maintaining a common international monetary standard, reflects, in part, a misassessment of the late 19th-century experience. How well the process of balancing payments between countries actually worked when exchange rates

Cato Journal, Vol. 8, No. 2(Fall 1988). Copyright @ Cato Institute. All rights reserved. The author is the William D. Eberle Professor of International Economics at Stanford University. 


\section{Cato Journal}

were fixed and capital markets were integrated has not been sufficiently distinguished from systemwide instability associated with gold itself.

In this paper I will contrast the classical Hume-Ricardo-Mill model of international payments adjustment under the gold standard-still the dominant textbook approach - with the modern (revisionist) view based on more integrated goods and financial markets. The case for or against flexible exchange rates largely depends on which of these perspectives one accepts.

First, however, I want to assess how well the 19th-century gold standard anchored the world price level. The problem of worldwide inflation and deflation is somewhat distinct from whether fixed exchange rates, based on mutual monetary adjustment, are desirable.

\section{The World Price Level}

For the period before 1914, data on wholesale prices are much easier to obtain than is direct information on output and employment. Roy Jastram (1977) pieced together a long time series, based on both British and American price data, to show that the real purchasing power of gold over a general basket of primary commodities and simple manufactures was virtually the same at the beginning of World War $I$ as it had been at the end of the Napoleonic wars a century earlier. Indeed, British data going back to the 18th century show a remarkable absence of any trend in gold's purchasing power.

A second characteristic of the gold standard-at least from the late 1870 s to 1913 when exchange rates were securely fixed-was the strength of international arbitrage in markets for tradable goods other than precious metals. Table 1 shows that the wholesale price levels of the United States, Great Britain, Germany, and France fell in parallel by the order of 40 to 50 percent from 1873 to 1896 , and then rose by a similar amount from 1896 to 1913 . At a more microeconomic level, McCloskey and Zecher (1976) provide additional evidence that the absolute prices of individual commodities were generally aligned internationally about as well as they were among different regions within the same country.

Thus, in the late 19th century, the world economy was successfully unified to the extent that prices of a broad basket of tradable goods were aligned across countries. When nominal exchange rates were securely fixed by mutual monetary adjustment, international commodity arbitrage was sufficiently robust to create purchasing power parity (PPP): Any one national currency had about the same real purchasing power in domestic markets for tradable commodities as 


\section{TABLE 1}

Wholesale Price Indexes for the United States, United Kingdom, Germany, and France. SEleCted Years, 1816-1913

\begin{tabular}{lrrrr}
\hline Year and Period & $\begin{array}{c}\text { United } \\
\text { States }\end{array}$ & $\begin{array}{c}\text { United } \\
\text { Kingdom }\end{array}$ & Germany & France \\
\hline Indexes $(1913=100)$ & & & & \\
1816 & 150 & 147 & 94 & 143 \\
1849 & 82 & 86 & 67 & 94 \\
1873 & 137 & 130 & 114 & 122 \\
1896 & 64 & 72 & 69 & 69 \\
1913 & 100 & 100 & 100 & 100 \\
Changes $(\%)$ & & & & \\
$1816-1849$ & -45 & -41 & -29 & -33 \\
$1849-1873$ & 67 & 51 & 70 & 30 \\
$1873-1896$ & -53 & -45 & -40 & -45 \\
$1896-1913$ & 56 & 39 & 45 & 45 \\
\hline
\end{tabular}

SourCE: Cooper (1982, p. 8).

it did abroad. (This was most unlike our recent experience with floating exchange rates.) Since one may then talk sensibly about a common world price level, can the mechanisms of the gold standard per se be credited with systematically stabilizing it over the long run-as Jastram's statistics might suggest?

Barry Eichengreen (1985, p. 7) clearly summarizes the classical view of how the common price level was anchored:

[Mill's] assumption was that the flow supply of newly mined gold would be responsive to relative prices. As the world economy expanded and the demand for money grew, downward pressure would be placed on the world price level. As the prices of other commodities fell in terms of the numeraire commodity gold, new supplies would be elicited by its rising value.... Similarly, to the extent that deflation causes the price of jewelry to fall in terms of gold coin, jewelry will be presented at the Mint for conversion into coin, increasing the quantity of coin in circulation and moderating the downward pressure on prices.

Robert Barro (1979) provides an algebraic exposition of these two forces and notes that "the determination of the absolute price level amounts to the determination of the relative price of the reserve commodity." Was then the price of gold relative to other commodities naturally constant so as to prevent secular change in the common price level? 


\section{Cato Journal}

From Table 2, Robert Triffin's (1964) analysis suggests the contrary. In the 19th century, only massive increases in the circulation of credit money (notes and deposits) prevented unending price-level deflation. Triffin shows that by 1885 token currency and demand deposits already constituted about 65 percent of the money supplies of Britain, France, and the United States, and that this proportion increased to 87 percent by 1913. Thus during this period, the mixed system had become largely a gold bullion standard with relatively slender reserves for meeting international payments concentrated in national treasuries and central banks.

These financial innovations were only loosely regulated at the national level. No authority with a worldwide view-not even the Bank of England--was monitoring or controlling the aggregate stock of credit money with an eye to stabilizing the world's price level. The fact that the world's price level was approximately the same in early 1914 as in 1814, therefore, seems to be largely accidental.

This absence of a dependable gold anchor for the common price level becomes evident once one looks at price movements over shorter time periods. In his thorough study of economic fluctuations under the pre-1914 gold standard, Richard Cooper (1982, p. 6) notes that

Price stability was not attained, either in the short run or in the long run, either during the gold standard proper or over a longer period during which gold held dominant influence. In fact, in the United States short-run variations in wholesale prices were higher during the prewar gold standard than from 1949 to 1979 . The standard deviation of annual movements in (wholesale) prices was 5.4 percent in the earlier period and only 4.8 percent in the latter period.

For longer-term cyclical fluctuations of a decade or two, Cooper offers the wholesale price index data in Table 1 for the United States, Great Britain, Germany, and France. The great deflations of the early 19th century were relieved only by the discovery of gold in California and Australia in 1849, and deflation was interspersed with depressions from 1873 to 1896 as more nations joined the gold standard, thereby causing a general shortage of gold reserves, which was not relieved until the South African and Yukon discoveries of the late 1890s. The inflations from 1849 to 1873 and from 1896 to 1913 were substantial, although not high by modern standards.

Periodic convertibility crises were a natural consequence of the buildup of credit money relative to the narrowing gold base. An "internal drain" within a country-not infrequently within some regions of the United States-could be triggered by a bank panic in which people rushed to cash in bank notes or deposits for gold. An "external drain" could arise out of (incipient) gold losses to foreigners 
through the balance of payments. Indeed, the development of central banking was largely a response to numerous convertibility crises. Whence Walter Bagehot's (1873) famous dictum that when a gold run developed, the national central bank should raise its discount rate to attract foreign funds, but then lend freely to domestic financial institutions to mitigate their reserve losses.

In summary, convertibility crises did not arise mainly because the gold standard was "international" - that is, because nations maintained fixed nominal exchange rates with each other and had to subordinate domestic money growth to the balance of payments. Individual countries could even, on occasion, meet an internal drain somewhat better if they could borrow in the London capital market. In the 19th century the world gold standard was less than fully stable because of the uneasy coexistence of gold and credit money. Moreover, the collective supply of the latter was not under the control of any supernational monetary authority that assumed responsibility for stabilizing the common price level.

\section{Two Views of International Adjustment}

In the integrated world economy with fixed exchange rates of the late 19th century, the world price level and economic conditions were determined by cyclical fluctuations in the overall supply of and demand for gold and by uneven secular growth in gold-based credit monies. But how did payments between individual countries remain in balance?

The classical theory comes down from the full-bodied gold standard and price-specie flow mechanism of David Hume (1752). Sometimes called the Ricardo-Mill adjustment mechanism, it remains the standard textbook approach to interpreting how the gold standard worked. This theory presumes that gold movements themselves were instrumental in balancing international payments through their effects on net trade flows. If a country developed a payments deficit, a loss of gold to the outside world would force an internal deflation that induced a rise in exports and fall in imports, and vice versa for surplus countries.

The classical approach was extended to include the mixed system of the later 19th century, characterized by a narrow gold base and a larger superstructure of credit money. Under the "rules of the game," central banks or treasuries were not to sterilize: A gold inflow would be allowed to expand the domestic money supply by some multiple of the inflow itself, and vice versa. In Great Britain these rules were formalized under the Bank Act of 1844 where note issue by the Bank 


\section{TABLE 2}

Comparative Evolution of Money and Reserve Structure, 1885 and 1913

\begin{tabular}{|c|c|c|c|c|c|c|}
\hline \multirow[b]{2}{*}{ Money and Reserves } & \multicolumn{2}{|c|}{ Three Countries $^{\mathrm{a}}$} & \multicolumn{2}{|c|}{ Eleven Countries $^{\mathrm{b}}$} & \multicolumn{2}{|c|}{ World } \\
\hline & 1885 & 1913 & 1885 & 1913 & 1885 & 1913 \\
\hline \multicolumn{7}{|l|}{ In Billions of U.S. Dollars } \\
\hline 1. Money Supply & 6.3 & 19.8 & 8.4 & 26.3 & 14.2 & 33.1 \\
\hline a. Gold & 1.4 & 2.0 & 1.8 & 2.7 & 2.4 & 3.2 \\
\hline b. Silver & 0.7 & 0.6 & 1.0 & 1.2 & 3.0 & 2.3 \\
\hline c. Credit Money & 4.1 & 17.2 & 5.6 & 22.4 & 8.8 & 27.6 \\
\hline i. Currency ${ }^{\mathrm{c}}$ & 1.6 & 3.8 & 2.3 & 5.9 & 3.8 & 8.1 \\
\hline ii. Demand Deposits & 2.6 & 13.3 & 3.3 & 16.5 & 5.0 & 19.6 \\
\hline 2. Monetary Reserves & 1.0 & 2.7 & 1.5 & 4.0 & 2.0 & 5.3 \\
\hline a. Gold & 0.6 & 2.1 & 0.9 & 3.2 & 1.3 & 4.1 \\
\hline b. Silver & 0.4 & 0.6 & 0.6 & 0.8 & 0.7 & 1.2 \\
\hline 3. Total Gold and Silver & 3.1 & 5.4 & 4.3 & 7.9 & 7.4 & 10.8 \\
\hline a. Gold & 2.0 & 4.1 & 2.7 & 5.9 & 3.7 & 7.3 \\
\hline b. Silver & 1.1 & 1.2 & 1.6 & 2.0 & 3.7 & 3.5 \\
\hline
\end{tabular}


In \% of Money Supply

\begin{tabular}{lrrrrrr} 
1. Money Supply & $\mathbf{1 0 0}$ & $\mathbf{1 0 0}$ & $\mathbf{1 0 0}$ & $\mathbf{1 0 0}$ & $\mathbf{1 0 0}$ & $\mathbf{1 0 0}$ \\
a. Gold & 23 & 10 & 21 & 10 & 17 & 10 \\
b. Silver & 11 & 3 & 12 & 5 & 21 & 7 \\
c. Credit Money & 66 & 87 & 67 & 85 & 62 & 83 \\
$\quad$ i. Currencyc & 25 & 19 & 27 & 22 & 27 & 25 \\
$\quad$ ii. Demand Deposits & 41 & 67 & 39 & 63 & 35 & 59 \\
2. Monetary Reserves & 16 & 14 & 18 & 15 & 14 & 16 \\
a. Gold & 9 & 11 & 11 & 12 & 9 & 12 \\
b. Silver & 7 & 3 & 7 & 3 & 5 & 4 \\
3. Total Gold and Silver & 49 & 27 & 51 & 30 & 52 & 33 \\
a. Gold & 32 & 21 & 32 & 22 & 26 & 22 \\
b. Silver & 17 & 6 & 19 & 8 & 26 & 11 \\
\hline
\end{tabular}

aUnited States, United Kingdom, and France.

'United States, United Kingdom, France, Germany, Italy, Netherlands, Belgium, Sweden, Switzerland, Canada, and Japan.

'Including subsidiary (nonsilver) coinage, except in last column.

SOuRCE: Triffin (1964, p. 56). 


\section{Cato Journal}

of England was restricted one-for-one to any marginal changes in its gold reserves. Thus, internal inflation or deflation was ensured so as to maintain external equilibrium through changes in the net trade balance.

Consider a more precise example of a disturbance in the flow of international payments, say, a new ongoing transfer of long-term capital from country A to country B. According to classical theory, adjustment would occur because gold flows in the same direction as the capital transfer and the resulting fall in A's money supply would induce general price-level deflation-across both tradable goods and nontradable services-in country $A$ and correspondingly general inflation in country $B$.

From the mid-18th century into the early 19th century, transport costs were perhaps such that only gold could be easily arbitraged to have a common price in both foreign and domestic markets (Marcuso and Rosselli 1987). Following gold movements, the prices of commodities other than precious metals could then fall in country $A$ as they rose in country $B$, as might be predicted by the quantity theory of money applied on a purely national basis. (By the late 19th century, however, international markets in potentially tradable commodities were too unified for such divergent price movements to occur.)

In particular, the price of tradable goods produced in country $\mathrm{A}$, measured at the prevailing fixed exchange rate, would decline relative to those produced in country B. This decline in A's terms of trade-the cheapening of A's export products relative to B's-is then seen (in the classical perspective) to be a principal mechanism by which A's exports increase and imports decrease so as to create a trade surplus. This surplus is the "real" counterpart of the capital transfer. Later authors in the classical tradition-from Viner (1924), Taussig (1927), and Keynes (1923, 1930) down to Friedman and Schwartz (1963)--place additional emphasis on absorption (and possibly income) decreases in country A and increases in country B. But induced changes in the relative prices of A's tradables vis-à-vis B's remained important for balancing international payments.

From this classical description of the adjustment mechanism, therefore, comes the popular image of the gold standard: In different countries domestic inflation rates continually moved in opposite directions. The stability of national price levels (and possibly employment and output) was hostage to (arbitrary) shifts in the international distribution of gold reserves arising out of disturbances in foreign trade or in capital flows. More generally, the classical view suggests that fixed exchange rates sacrifice domestic macroeconomic stability to the need for balancing international payments. 
The revisionist view of how international payments remained balanced begins with the observation that the classical adjustment mechanism is inconsistent with price-level data of the sort displayed in Table 1. Instead of moving in opposite directions, national price levels moved up and down together over periods of several years (Triffin 1964; Cooper 1982), as did prices of individual tradable commodities (McCloskey and Zecher 1976; Dick and Floyd 1987). Indeed, therein lay the attractiveness of the fixed-rate 19th-century system: It provided a common international standard of value.

When exchange rates were fixed for a long period, generalized commodity arbitrage became sufficiently strong to prevent the prices (exclusive of tariffs) of any particular tradable good (for example, cotton shirts) from differing significantly more across countries than they did interregionally within a country. ${ }^{1}$ Similarly, overall price levels of tradable goods, as measured by national wholesale price indices, remained aligned and did not change in a Humean fashion in response to gold flows.

With changes in relative national price levels thus restricted, what was the adjustment mechanism for the large net transfers of real capital from one country to another from 1870 to 1913? How did capital-receiving countries, such as those of North and South America, develop trade deficits while the capital-donating countries, largely in Western Europe, generated corresponding trade surpluses?

By the late 19th century, a large and sophisticated international capital market centered in London had developed for both shortterm trade bills of exchange and longer-term bond and equity issues that could be, and were, purchased by foreigners as well as Britons (Arndt and Drake 1986). Through modest adjustments in relative interest rates, expenditure patterns across countries were coordinated so as to match trade surpluses and deficits with net capital flows (Whale 1937; Williamson 1964). In effect, the international integration of capital markets complemented the integration of markets in tradable goods so that little or no net gold flows-let alone changes in exchange rates-were necessary to effect these capital transfers. Adjustments in international payments were similar to adjustments within a country or a single currency area.

Consider the flotation of a large new issue of American railway bonds in the 19th-century London capital market. Under the classical adjustment mechanism, this transfer would be treated as an exogenous force inducing gold to flow into the United States, causing

\footnotetext{
${ }^{1}$ Only when exchange rates float freely and, thus, unpredictably is the law of one price
} systematically violated, as it has been in recent years (Isard 1977; Levich 1986). 


\section{Cato Journal}

inflation, and out of Great Britain, causing deflation. From the revisionist perspective of integrated financial and goods markets, however, the capital transfer would naturally reflect an upward propensity to spend for goods and services in the United States coupled with a similar reduction in Great Britain. That is, British financial saving, which would otherwise be transmuted to domestic investment, would simultaneously be diverted to support an increase in spending in the United States. So the changes in national levels of absorption (aggregate spending) would naturally create a British trade surplus with the United States that was a counterpart of the net capital transfer.

To the extent the British trade surplus fell short of (or exceeded) the total proceeds from the issue of railway bonds, an offsetting inflow (or outflow) of short-term capital to London would be the residual balancing item. Indeed, short-run interest rates could well adjust so that the funds were kept on deposit in London until disbursed "smoothly" through time to finance the American trade deficit. Only very small changes in international interest differentials would be necessary to maintain this payments balance as long as exchange rates remained credibly fixed.

In contrast to the classical view, gold flows would not be an instrumental or "forcing" variable in this adjustment process. Indeed, the initial flotation of railway bonds need not have any predictable impact on net gold flows, although they might respond ex post to differing rates of national income growth and increases in money demand (Abramovitz 1973; McCloskey and Zecher 1976).

What happens to relative prices in the revisionist adjustment process? Here it is important to distinguish between (1) the terms of trade: the relative price of a broad basket of British exports (largely manufactures) and American exports (largely primary products in the 19th century); and (2) the prices of tradable goods relative to nontradables within Great Britain and within the United States.

The classical adjustment mechanism does not distinguish between (1) and (2). That is, a forced gold flow, causing general price deflation in Great Britain and general price inflation in the United States, tends to lower British prices across the board relative to their American counterparts, with the possible exception of precious metals that can be easily arbitraged. Thus, the classical theory presumes that Great Britain's terms of trade would deteriorate, which imposes a secondary burden on the capital-donating country. Also, because some British goods have higher transport costs and are less tradable than other goods, their relative prices would fall further. The reverse pattern would hold in the United States. 
In the revisionist view based on a more integrated world economy, however, there is no presumption that the terms of trade need change as a result of a capital transfer as long as exchange rates are fixed so that the law of one price holds for each tradable good. Although the relative prices of nontradables might be bid up in the United States and down in Great Britain, there is a presumption that all such changes would be moderate and possibly only temporary. To effect even large net transfers of capital, the "need" for broad changes in relative commodity prices would seem quite modest in final equilibrium when trade and capital movements are balanced. ${ }^{2}$

\section{The Law of One Price under Fixed and Floating Exchange Rates}

One common justification for allowing exchange rates to float (Frenkel 1987) is to provide greater flexibility in allowing the prices of goods and services of country $A$ to vary collectively vis-à-vis those in country B. In modern industrial economies, the invoice prices of manufactures, which are largely brand-specific, are quite rigid or "sticky" in the currency of the country where they originate (Grassman 1973; McKinnon 1979) and, temporarily, in the destination country. Thus a sudden (unexpected) depreciation of A's currency will

(i) violate the law of one price in a narrow sense: The same brandname good will sell for days or weeks at a lower price in country A than the price in country $B$ evaluated at the current exchange rate;

(ii) violate the law of one price in a broad sense: the prices of A's products similar (in the sense of models of monopolistic competition) to those in B will be sold at lower prices, possibly for many months or quarters; and

${ }^{2}$ This difference between the classical and the revisionist perspective parallels the famous 1929 debate between J. M. Keynes and Bertil Ohlin on whether the war reparations owed by Germany to the rest of Europe would necessarily turn the terms of trade against Germany and thus impose a secondary burden on the German economy beyond the transfer itself. By emphasizing the need for Germany's terms of trade to decline in order for a German trade surplus to develop, Keynes took the classical position on how the capital transfer would be effected.

Ohlin was the "revisionist." He argued as if the German economy were more fully integrated into the rest of Europe. The fall in absorption in Germany, coupled with a rise in the capital-receiving countries, would effect the transfer without substantially turning the terms of trade against Germany.

In retrospect, who was right seems to be more of an empirical question-how open was the postwar German economy-than a theoretical one. For the principal articles and rejoinders of Keynes and Ohlin, see Economic Journal 39 (1929): pp. 1-7, 172-82, and 400-408. 
(iii) products unique to A will sell at lower prices compared with those unique to $B$, perhaps for several years if the depreciation were to persist.

In all three senses, the sudden depreciation of A's currency turns the terms of trade against country A. Moreover, under floating exchange rates with given national money supplies (present and future), the "normal" effect of an ex ante transfer of financial capital from A to B is to depreciate A's currency against B's (Johnson 1956). Thus, under floating, one expects a "forced" deterioration in A's terms of trade in response to a capital outflow-a deterioration similar to that posited by the classical theory of adjustment to a capital outflow under the gold standard. A modern example was the large 1980-84 depreciation of European currencies against the dollar in response to a flow of private capital into the United States. Thus, in a regime of floating exchange rates, there is a strong presumption that the terms of trade will turn against the transferor and in favor of the transferee.

But is such an abrupt change in relative prices, particularly in the terms of trade, warranted if economies could potentially be integrated under fixed exchange rates? Is the acute sensitivity of a floating exchange rate to shifts in international portfolio preferences a "correct" response for facilitating a trade surplus for $A$ and a deficit for B? The late 19th-century experience with fixed exchange rates suggests otherwise: Capital flowed from Europe to Canada and the United States without inducing or requiring substantial increases in the North American terms of trade-certainly nothing like the U.S. dollar's 40 to 50 percent appreciation in the early $1980 \mathrm{~s}^{3}$

\section{Alternative Pure Trade Models of the Transfer Problem}

For a moneyless world, pure trade theory offers several formal models based on barter and continuous full employment. To supplement historical experience, these models can throw additional light on how relative prices, including the terms of trade, should change in response to a capital transfer.

However, the implicit monetary mechanism that underlies, or is at least consistent with, the pure trade model must be made explicit. ${ }^{4}$

${ }^{3}$ For evidence on the Canadian experience, see Dick and Floyd (1987).

${ }^{4}$ As Samuelson (1971, pp. 327-28) noted, "Analytically, the discussion [of the transfer problem] remained confused, because models involving effective demand and financial considerations were rarely carefully separated from those involving pure barter." And in a series of articles beginning in the early 1950s, Samuelson himself could not make up his mind whether the orthodox presumption was correct: that a financial transfer would turn the terms of trade significantly against the transferor. To this day, a satisfactory general equilibrium model, incorporating real and financial considerations, remains to be constructed. 
All of the pure trade models reviewed below assume that the law of one price for tradable goods always holds in both the narrow and broad senses discussed above. To this extent, therefore, these models implicitly assume a regime of fixed exchange rates (or a single currency area) linking foreign and domestic economies. This assumption, nevertheless, leaves open the possibility that terms of trade between dissimilar goods may vary. Although exchange rates are (implicitly) fixed, the prices of nontradable services, the provision of which requires close geographic proximity, may still vary.

In his article "Presumption and the Transfer Problem," Ronald Jones (1975) built a model with two trading economies. Each produced and consumed a nontradable commodity with prohibitively high international transport costs, an exportable (the other's importable), and an importable (the other's exportable) whose relative prices were free to vary. Because each produced nontradables as well as close substitutes for the other's exportables, Jones's model effectively assumed that the two were industrially diversified (as opposed to monoproduct) economies.

While fully mobile within each country, neither labor nor capital were internationally mobile in two important respects. First, there was no direct ongoing factor movement across national boundaries. To encapsulate the transfer problem, Jones did consider a one-time increase in the flow of capital out of the home country that was experiencing reduced domestic expenditures and corresponding increases abroad. But he assumed no ongoing financial linkage that would equalize interest rates between the two countries. Second, Jones did not assume that the two countries needed to be in the factor price equalization region: Trade alone does not equalize factor prices.

Instead, Jones simply posited that all three goods were gross substitutes in production and consumption within each country-with given, possibly heterogeneous, factor supplies. The two economies were integrated in trade flows but not in factor markets, thus leaving relative commodity prices free to vary.

Jones then demonstrated (1975, p. 265) that the transferor's or home country's terms of trade deteriorate if and only if

$$
m_{2}{ }^{*}+\theta^{*} m_{3}{ }^{*}>m_{2}+\theta m_{3} .
$$

The $m$ parameters are expenditure propensities (arising out of the capital transfer), asterisks represent the foreign country, commodity 2 is the home importable (foreign exportable), and commodity 3 is the nontraded good in each country. An alternative inequality condition could be restated in terms of commodities 1 (the home coun- 
try's exportable) and 3. If (1) holds, the home country's terms of trade $P_{1} / P_{2}$ fall during the transfer-the orthodox presumption.

The parameters $\theta$ and $\theta^{*}$ are complex and reflect price substitution effects across the three commodities within each country. They would be identical if the two countries were symmetrically diversified in their production and consumption characteristics. Suppose they were so diversified.

Whether inequality (1) is satisfied, therefore, largely depends on whether each country's marginal propensity to spend on its own exportable exceeds the trading partner's propensity to spend on the same good (the partner's importable), that is, whether $m_{2}{ }^{*}>m_{2}$. The fall in home country expenditures tends to reduce the relative price of the foreign exportable $\left(P_{2}\right.$ tends to fall relative to $\left.P_{1}\right)$, but the rise in expenditures abroad tends to raise its relative price. And which effect is stronger remains an open empirical question for industrially diversified economies. There is no theoretical presumption that the terms of trade of the transferor need deteriorate, that is, for (1) to hold, unless one makes more specialized assumptions about patterns of production and consumption.

Paul Krugman (1987a, 1987b), for example, makes such specialized assumptions in order to support the orthodox (classical) presumption that the terms of trade of the transferor will deteriorate. In the modern context, he asks: "Suppose the United States were to increase tax revenues (reduce the fiscal deficit) by 100 billion dollars and stop borrowing that much in the international capital market. For the U.S. trade balance to improve by a similar amount, would the terms of trade have to turn against the United States?"

Krugman then assumes that the United States produces only one good, some of which it exports and most of which it consumes at home. The United States does not produce import substitutes while it consumes imports nor is there a distinct category of nontradables. In contrast to the Jones model, the industrial structure in Krugman's model is not diversified. The rest of the world (ROW) is similarly a monoproduct economy. ROW consumes most of the single good it produces, while exporting the rest, and consumes some of the American good. (In common with the Jones model, however, Krugman's does not assume that factor markets are integrated with a tendency toward factor price equalization.)

With this analytical machinery based on nondiversified (monoproduct) economies in place, the orthodox presumption seems very strong: As the American trade balance adjusts to the reduced capital inflow, the terms of trade are likely to turn against the United States. 
Specifically, Krugman shows that the orthodox presumption will hold if and only if

$$
m+m^{*}<1
$$

where the $m$ parameters are now distinguished from inequality (1) above. Here, $m$ is the more narrowly defined marginal propensity to import of the United States. (The $m$ parameter is identical to the marginal propensity to spend on importables, $m 2$ above, only in monoproduct economies.) Parameter $m^{*}$ is ROW's similarly defined marginal propensity to import. Krugman provides empirical evidence to suggest that $m$ and $m^{*}$ are each much less than 0.5. Indeed, if one looks only at the share of imports in either American or ROW GNP, they are 0.2 or less, although Krugman recognizes that marginal propensities are likely to be a bit higher.

So (2) appears to be satisfied in practice, leading Krugman to take the orthodox view that the American terms of trade must deteriorate if the trade deficit is to be reduced by the full hypothetical increase in tax revenues. Further, because domestic prices of manufactured tradables are "sticky" in the United States and in ROW, he suggests some large nominal devaluation of the dollar would be justified to bring about the needed reduction in the American terms of trade. (This leaves open the important question of whether the requisite American fiscal adjustment is imminent, and whether dollar devaluation should precede, coincide with, or follow the $\$ 100$ billion tax increase.)

But remember that inequality (2) is a sufficient condition for the orthodox presumption only if one accepts Krugman's simplifying assumption that both the United States and ROW are monoproduct economies. If, instead, both economies are diversified in the sense of Jones (1975) or Dornbusch (1975), then (2) may hold even if the orthodox presumption is invalid. Even though observed import shares in GNP are quite small, the transfer can be effected without having the terms of trade turn against the United States. Jones's model, based as it is on diversified free-trade economies, better represents the industrial world today as well as that of the late 19th century, although not necessarily in the intervening decades.

Left unanalyzed is the more naive, but commonly held, view that dollar devaluation alone-without a complementary change in the fiscal deficit-will reduce the dollar value of the American trade deficit. More generally, the old elasticities approach (Bickerdike 1920; Robinson 1939; Metzler 1949) suggested that exchange rate changes themselves have a systematic effect on net trade balances. That this latter presumption is false for open, diversified economies 
is demonstrated analytically in Dornbusch (1975) and McKinnon and Ohno (1986) and is borne out by the failure of the American trade deficit to respond to dollar devaluation from 1984 to 1988.

\section{An Exchange Rate Dilemma When Factor Markets Are Not Integrated}

Barter models of exchange suggest that the terms of trade need not move substantially to bring about a capital transfer between economies with diversified foreign trade in goods and services. Whether the change in the terms of trade is negative or positive, the point at which final equilibrium is achieved remains unknown a priori. Unlike what Krugman's model suggests, using the nominal exchange rate as an instrument to influence the terms of trade during the transfer process seems neither necessary nor desirable.

When foreign and domestic factor markets are not integrated, however, the price of the domestic nontradable must still decrease (relative to tradables) in the transferor's economy and increase within the transferee's. In his pure trade model, Jones (1975) derives this unambiguous result algebraically, but it is clear intuitively under a fixed exchange rate regime. The capital transfer is associated with reduced spending in the home country, pressure from which then reduces the prices (using foreign exchange as the numeraire) of those goods and services not arbitraged in international markets. The home trade balance then improves as resources are released from the nontradables sector to produce more exportables and importables-with the reverse adjustment occurring abroad.

Now return to monetary economies where nominal prices may be quoted in different currencies. In addition, suppose that the domestic currency prices of both nontradables and domestically produced tradables are "sticky" at home and abroad. When the capital transfer occurs, would movement in the nominal exchange rate help speed the necessary adjustments in equilibrium relative prices by overcoming this price stickiness? Specifically, would the orthodox policy of having the home country devalue its currency reduce the relative prices of nontradables without causing "false" changes in other relative prices, and without impeding the process by which expenditures are naturally reduced at home and increased abroad? The short answer is "no." If substantial devaluation occurs, incidental price and absorption effects both go in wrong directions.

First, the primary effect of devaluation is to reduce the transferor's terms of trade with the transferee-and not raise the relative price of tradables to nontradables within the home country while reduc- 
ing it abroad. The domestic currency prices of direct imports are typically sensitive to the exchange rate, even though prices of the great mass of domestically produced exportables and import substitutes are not. With full pass-through, a devaluation may quickly raise import prices vis-à-vis those of domestically produced tradables. ${ }^{5}$ The law of one price is violated and the terms of trade turn against the transferor in the three senses discussed above. But there is no presumption that the terms of trade should or need to change in final equilibrium; thus, these price "misalignments" likely will need to be corrected at a later stage in the transfer process. In the short run, the devaluation introduces confusing noise into the price system.

At the same time, the devaluation succeeds in raising the prices of tradables relative to nontradables only in a limited, fragmented way. The prices of direct imports increase, but not the overall prices of domestically produced tradables. More important, the extreme changes observed in the mark/dollar and yen/dollar exchange rates in recent years-sometimes nearly 40 or 50 percent-seem to be much too high (see below) for any conceivable warranted adjustments in the average price of tradables relative to nontradables.

Second, a devaluation may induce absorption to adjust the wrong way in both the transferor's and transferee's economies, and thus impede the capital transfer. Because domestic invoice prices are sticky, they do not jump with the exchange rate. But they do adjust with a lag, albeit quite long. After devaluation by the transferor, expectations of ongoing domestic inflation will increase, raising the private propensity to spend for goods and services in that country. Similarly, expectations of deflation in the transferee will reduce peoples' propensity to spend there (McKinnon and Ohno 1986; Kim 1987). These perverse absorption effects then delay the emergence of the transferor's trade surplus, which is the real counterpart of the transfer of financial capital.

\section{Alternative Exchange Rate Systems and the International Integration of Factor Markets}

However, if factor markets between economies with similar levels of technical proficiency are effectively integrated, even the relative

${ }^{5}$ Unlike other industrial economies such as Germany, immediate pass-through into the domestic prices of direct imports is not typical of the United States (Knetter 1988). Despite changes in the dollar exchange rate, exporters to the United States prefer to keep their dollar price quotes to American customers rather more rigid-perhaps because of the American economy's large size, and the dollar's central position in the world monetary system. 


\section{Cato Journal}

prices of tradables and nontradables need not adjust significantly when a transfer occurs. The ongoing international arbitrage in markets for tradable goods and in financial capital keeps both economies in the "factor-price equalization region." Because the nontradable goods industry in each country is then a price taker in factor markets facing the same real wage and real rental rate on capital, the relative price of nontradables need not change as their output varies during the transfer process (Samuelson 1971).

Whether international monetary arrangements support the ongoing arbitrage in goods and financial markets necessary to keep economies in, or close to, the equalization region is an open question. One condition is that the law of one price holds in international markets for tradable goods. A second is that financial arbitrage must be effective in equalizing real interest rates-nominal rates minus anticipated price inflation-across countries.

Unfortunately, both conditions have been continually violated under the system of fluctuating exchange rates we have observed over the past 15 years. Internal price and wage stickiness in the major industrial economies implies that unexpected changes in exchange rates continually disrupt commodity market arbitrage: The law of one price is violated in both the narrow and broad senses. This failure of tradable goods markets to remain integrated, that is, the failure of purchasing power parity between national monies, reduces indirect pressure to equalize factor prices across countries.

More subtly, direct financial arbitrage-even today's massive (gross) capital flows among Europe, Japan, and the United States-fails to equate real interest rates across countries as long as exchange rates float and (relative) purchasing power parity is violated. Because goods markets are imperfectly integrated, national rates of price inflation can differ from expected changes in exchange rates, which may dominate differences in nominal interest rates (Frankel 1986). For example, from 1981 to mid-1985, the dollar was obviously overvalued against the yen and mark by the PPP criterion, and survey data showed that financiers expected the dollar to depreciate (Frankel and Froot 1987). Thus, U.S. nominal interest rates remained much higher than in Japan or Germany, even though national rates of price inflation were not much different. Real interest rates were not equalized.

As a result, the modern system of fluctuating relative currency values severely impairs the allocative efficiency of the international capital market. Countries go through alternating cycles of underinvestment or overinvestment in tradable goods industries, depending on whether their currencies are overvalued or undervalued by 
the PPP criterion. The increased exchange risk inhibits industrial investment everywhere.

Here, the 19th-century system, based on fixed exchange rates and mutual monetary adjustment to provide a common standard of value, seems much preferred. Arbitrage in internationally tradable goods then became sufficient to approximate the law of one price. In financial markets the commitment to fixed nominal exchange rates had two related effects. First, nominal interest rates were closer together and, on average, lower. Second, price inflation was more uniform across countries. International financial arbitrage could succeed in keeping real interest rates closer together.

But is the present degree of economic integration among the principal industrial economies sufficient to warrant establishing a common monetary standard with fixed exchange rates? Table 3 indicates that the intensity of merchandise trade in the 1980s is again comparable to what had been achieved by 1913 . With the elimination of exchange controls in Europe and Japan, arbitrage pressures in international financial markets seem at least as great as they were before World War I. If exchange rates were to become credibly fixed once more, commodity and financial arbitrage should again serve to keep industrial nations within, or close to, the region of factor price equalization.

Moreover, Table 4 indicates that the average net transfer of capital out of Britain between 1905 and 1914 was more than half of net national saving-proportionately much higher than the large trade surpluses generated by Japan and Germany (or trade deficit of the United States) in the mid-1980s. In this sense, the "need" for broad

TABLE 3

Proportions of Merchandise Trade to National Product for Major Developed Economies

\begin{tabular}{lccc}
\hline $\begin{array}{l}\text { Ranked by } \\
\text { Economic Size } \\
\text { in } 1984\end{array}$ & Pre-World War I & $1950 \mathrm{~s}$ & 1984 \\
\hline United States & 11.0 & 7.9 & 15.2 \\
Japan & 29.5 & 18.8 & 24.2 \\
Germany & 38.3 & 35.1 & 52.8 \\
France & 35.2 & $n / \mathrm{a}$ & 40.2 \\
United Kingdom & 43.5 & 30.4 & 47.0 \\
Italy & 28.1 & 25.0 & 44.6 \\
Canada & 32.2 & 31.2 & 47.3 \\
\hline
\end{tabular}

SOURCE: Wolf (1987). 
TABLE 4

Net Capital Outflows

\begin{tabular}{lccc}
\hline & $\begin{array}{c}\text { Gross National } \\
\text { Savings }\end{array}$ & $\begin{array}{c}\text { Gross Domestic } \\
\text { Fixed Investment }\end{array}$ & $\begin{array}{c}\text { Current } \\
\text { Account }\end{array}$ \\
\hline United States 1985 & 16.5 & 18.6 & -2.9 \\
Japan 1985 & 31.4 & 27.5 & 3.7 \\
West Germany 1985 & 22.2 & 19.5 & 2.2 \\
\hline United Kingdom & & & \\
1905-14 & 16.0 & 7.0 & 8.0 \\
\hline
\end{tabular}

SOURCE: Wolf(1987).

changes in relative prices to help effect capital transfers would seem to be less now than in the earlier era. And, among modern industrial economies, this paper suggests that exchange rate changes can be ambiguous, even perverse, in bringing about whatever adjustments in relative prices that might be needed to keep net trade balances in line with warranted net capital flows.

\section{Lessons from the 19th Century}

The strengths and weaknesses of the 19th-century gold standard must be carefully assessed to draw any useful lessons for presentday monetary arrangements.

Consider the positive side first. By binding nations togetheralbeit sometimes grudgingly-with what was a common price level, the system completely avoided the sudden and dramatic changes in relative international competitiveness characteristic of floating rates in the 1970s and 1980s. This common monetary standard permitted a much more efficient international allocation of capital: Financial arbitrage could better succeed in equalizing real interest rates while keeping European and North American economies within (or close to) the region of factor price equalizaton.

Moreover, the reality of international adjustment was quite different from its usual treatment in modern textbooks. Large net transfers of capital from country A to country B did not require a major deflation for $A$ to run a trade surplus, nor a major inflation for $B$ to run a trade deficit. At unchanged nominal exchange rates, capital transfers took place quite smoothly with apparently little need for one country's price level to change in any substantial way vis-à-vis another's. In short, that the gold standard was truly international was its greatest virtue. 
But worldwide deflation or inflation was a problem for the 19thcentury system because the underlying base of gold and credit monies was not properly anchored. Much American Populist hostility at the time-with present-day echoes-was concerned with strong deflationary pressure and recurrent depressions from the 1870 s to the mid-1890s. Because these pressures were not peculiar to the United States, fixed exchange rates per se, requiring American monetary policy to adjust to an international standard, have been "unfairly" identified as creating excessive domestic cycles of inflation or deflation. Rather, the problem lay with basing the international standard on gold.

Now North America, Western Europe, and Japan are as mutually dependent on trade and finance as were the former two a century ago. If exchange rates were again credibly fixed through mutual monetary adjustment, the "natural" nominal anchor for the system as a whole would be the common price level over internationally tradable goods, which can be approximated by wholesale or producer price indices. And, through joint management of the underlying base of national credit monies, the triumvirate could keep the new international monetary standard more stable than its 19th-century counterpart. ${ }^{6}$

\section{References}

Abramovitz, Moses. "The Monetary Side of Long Swings in U.S. Economic Growth." Memorandum 146. Center for Research on Economic Growth, Stanford University, 1973.

Arndt, Helmut, and Drake, Peter. "Bank Loans or Bonds: Some Lessons of Historical Experience." Banca Naziorale del Lavoro Quarterly Review (December 1985): 373-92.

Bagehot, Walter. Lombard Street. Reprint of 1915 edition. New York: Arno Press, 1969.

Barro, Robert. "Money and Price Level under the Gold Standard." Economic Journal 89 (March 1979): 13-27.

Bickerdike, C. F. "The Instability of Foreign Exchange." Economic Journal 30 (March 1920): 118-22.

Cooper, Richard N. "The Gold Standard: Historical Facts and Future Prospects." Brookings Papers on Economic Activity (1982): 1-45. Reprinted in Richard N. Cooper, The International Monetary System. Cambridge: MIT Press, 1987.

6See McKinnon (1984, 1988) for an overall description of how mutual monetary adjustment could be organized; and McKinnon and Ohno (1988) on the specific question of how "starting" exchange rates could be set so as to bring national price and wage levels into approximate alignment. 


\section{Cato Journal}

Dick, Trevor, and Floyd, John. "Canada and the Gold Standard: 1871-1913." Manuscript. July 1987.

Dornbusch, Rudiger. "Exchange Rates and Fiscal Policy in a Popular Model of International Trade." American Economic Review 65 (December 1975): 859-71.

Eichengreen, Barry. "Editor's Introduction." In The Gold Standard in Theory and History, pp. 1-36. Edited by B. Eichengreen. New York: Methuen Press, 1987.

Frenkel, Jacob A. "International Capital Mobility and Crowding Out in the U.S. Economy." In The Increasing Openness of the U.S. Economy, pp. 3369. Edited by R. Hafer. Federal Reserve Bank of St. Louis, 1986.

Frenkel Jacob, A. “The International Monetary System: Should It Be Reformed?” American Economic Review 77 (May 1987): 205-10.

Frenkel, Jacob A., and Froot, Kenneth. "Using Survey Data to Test Standard Propositions Regarding Exchange Rate Expectations." American Economic Review 77 (March 1987): 93-106.

Friedman, Milton, and Schwartz, Anna. A Monetary History of the United States, 1867-1960. Princeton: Princeton University Press, 1963.

Grassman, Sven. "A Fundamental Symmetry in International Payments Patterns." Journal of International Economics 6 (May 1976): 105-6.

Hale, David. "Will We Hate Japan as We Hated Britain?" The International Economy 2 (January/February 1988): 84-91.

Hume, David. Of the Balance of Trade. 1752. Reprinted in Writings on Economics. Edited by E. Rotwein. Madison: Wisconsin University Press, 1955.

Isard, Peter. "How Far Can We Push the Law of One Price?" American Economic Review 67 (1977): 942-48.

Jastram, Roy. The Golden Constant: The English and American Experience, 1560-1976. New York: John Wiley and Sons, 1977.

Johnson, Harry. "The Transfer Problem and Exchange Stability." Journal of Political Economy 64 (June 1956): 212-25.

Jones, Ronald. "Presumption and the Transfer Problem." Journal of International Economics 5 (1975): 263-74.

Keynes, John M. A Tract on Monetary Reform. London: Macmillan, 1923.

Keynes, John M. "The German Transfer Problem." Economic Journal 39 (March 1929): 1-7.

Keynes, John M. A Treatise on Money. London: Macmillan, 1930.

Kim, Yoonbai. "International Transfers of Capital and the Role of the Terms of Trade." Economics Department, Stanford University, February 1987.

Knetter, Michael. Export Price Dynamics: Theory and Evidence. Ph.D. diss., Stanford University, 1988.

Krugman, Paul. "Adjustment in the World Economy." Occasional Paper 24, Group of 30, 1987.

Krugman, Paul. "Exchange Rates and International Adjustment." Manuscript. September 1987.

Levich, Richard. "Gauging the Evidence on Recent Movements in the Value of the Dollar." In The U.S. Dollar: Recent Developments, Outlook, and Policy Options, pp. 1-28. Federal Reserve Bank of Kansas City, 1986. 


\section{GOLD STANDARD WITHOUT GOLD}

McCloskey, Donald, and Zecher, Richard. "How the Gold Standard Worked: 1880-1913." In The Monetary Approach to the Balance of Payment. Edited by Jacob A. Frenkel and Harry G. Johnson. London: Allen and Unwin, 1976.

McKinnon, Ronald I. Money in International Exchange: The Convertible Currency System. New York: Oxford University Press, 1979.

McKinnon, Ronald I. An International Standard for Monetary Stabilization. Washington, D.C.: Institute for International Economics, 1984.

McKinnon, Ronald I. "Monetary and Exchange Rate Policies for International Financial Stability: A Proposal." Journal of Economic Perspectives 2 (Winter 1988): 83-103.

McKinnon, Ronald I., "Purchasing Power Parity as a Monetary Standard." Economics Department, Stanford University, October 1988.

McKinnon, Ronald I., and Ohno, Kenichi. "Getting the Exchange Rate Right: Insular Versus Open Economies.” Economics Department, Stanford University, December 1986.

Marcuzzo, Maria., and Rosselli, Annalisa. "Profitability in the Early History of the Intemational Gold Standard." Economica 54 (August 1987): 367-80.

Metzler, Lloyd A. "The Theory of International Trade." In A Survey of Contemporary Economics, pp. 210-14. Edited by H. Ellis. Philadelphia: Richard Irwin for the American Economic Association, 1949.

Ohlin, Bertil. "The Reparation Problem: A Discussion." Economic Journal 39 (June 1929): 170-78.

Robinson, Joan. "The Foreign Exchanges." In Readings in the Theory of International Trade, pp. 83-103. Edited by H. Ellis and L. A. Metzler. Homewood, Ill.: Blakiston, 1950.

Samuelson, Paul. "On the Trail of Conventional Beliefs about the Transfer Problem." In Trade, Balance of Payments, and Growth. Edited by Jagdish Bhagwati, et al. Amsterdam: North-Holland, 1971.

Taussig, Frank W. International Trade. New York: Macmillan, 1927.

Triffin, Robert. "The Evolution of the International Monetary System: Historical Reappraisal and Future Perspectives." Princeton Studies in International Finance, no. 18, June 1964.

Viner, Jacob. Studies in the Theory of International Trade. New York: Harper and Brothers, 1937.

Whale, Philip B. "The Working of the Prewar Gold Standard." Economica 6 (February 1937): 18-32.

Williamson, Jeffrey G. American Growth and the Balance of Payments, 1820-1913. Chapel Hill: University of North Carolina Press, 1964.

Wolf, Martin. "The Need to Look to the Long Term." Financial Times, 16 November 1987. 


\section{The McKinnon Standard: How Persuasive?

\author{
Rudiger Dornbusch
}

Ronald McKinnon never fails to be insightful and provocative at the same time. His highly suggestive discussion of relative price variability under alternative monetary regimes forms part of a new research direction that was initiated in particular by Alan Stockman (1983) and Michael Mussa (1986). His discussion of a new monetary standard, a gold standard without gold, is a challenge to the current nonsystem.

I will in my comments touch on three issues: First, what can be said of adjustment mechanisms in international payments theory. Second, what do we know about relative price variability under alternative regimes and how does this variability relate to the law of one price. Third, how persuasive is the case for the McKinnon standard.

\section{The Adjustment Mechanism in International Payments}

McKinnon makes much of a distinction between traditional and revisionist interpretations of the adjustment mechanism under the gold standard: Do relative prices have to move in the course of payments adjustment, or to effect a transfer? And if so, which relative prices must move: exports relative to imports, or home goods relative to tradables?

As in all interpretations of classical literature, and more generally in talmudic pursuits, different scholars emerge with different findings, the ones coming late usually calling themselves revisionist. I have little doubt that Jacob Viner, the great scholar of classical writing

Cato Journal, Vol. 8, No. 2(Fall 1988). Copyright (c) Cato Institute. All rights reserved.

The author is the Ford International Professor of Economics at the Massachusetts Institute of Technology. 


\section{Cato JournaL}

on the adjustment mechanism, ${ }^{1}$ would have dismissed the McKinnon revisionism with little sympathy.

A standard rendition of the payments mechanism under Ricardian assumptions goes as follows: ${ }^{2}$ An income transfer, reparation payment, or loan from $A$ to $B$ raises spending in $B$ and reduces it in $A$. The spending increase in $B$ raises demand for home goods and for tradables as well; abroad spending on nontradables and tradables declines. With identical tastes (the central classical assumption), the spending changes in the world traded goods markets offset each other. But there will be excess demand in B's home goods market and in the market for labor, and an excess supply in A. Wages and all prices of goods produced in B will rise, and in A they will decline. Thus in B the terms of trade will improve and the price of home goods will rise in terms of importables, though not in terms of exportables under Ricardian assumptions about technology. In A, the transferring country, the real price of home goods will decline in terms of importables.

The price level as measured by consumer prices will decline in the transferring country, while it will rise in the country receiving the loan. Thus Ricardo's dictum “in borrowing countries prices are high" is borne out by the analysis. Much of the discussion of Viner (1924), Graham (1922), Taussig (1928), and Williams (1920) revolves around the question of what precisely the evidence is. None of that literature offers evidence to support that, contrary to classical writing, relative prices did not play a role in the adjustment process. It is regrettable that McKinnon did not dig deeper into this rich literature and fell all too quickly for revisionism.

\section{Relative Prices and Monetary Regimes}

Michael Mussa (1986) showed persuasively that the variability of real exchange rates, measured for example by bilateral relative price levels, increases sharply in the transition from fixed to flexible rates. Figure 1 shows the example of the U.S.-German real exchange rate. The immediate objection might be that the increased volatility might be the result not of the exchange rate regime per se, but rather of an increased level of noise in the world economy-oil shocks being the obvious example. But Mussa persuasively shows that for countries like Canada who have used flexible rates at various times increased variability is always the consequence of moving to a flexible rate

${ }^{1}$ See Viner (1955), Angell (1965), Harrod (1934), Hawtrey (1928), Mints (1945), and, especially, Iversen (1935).

${ }^{2}$ See Dornbusch, Fischer, and Samuelson (1977). 
FIGURE 1

U.S.-Germany: Real Exchange Rate Changes (Percent Per Month)

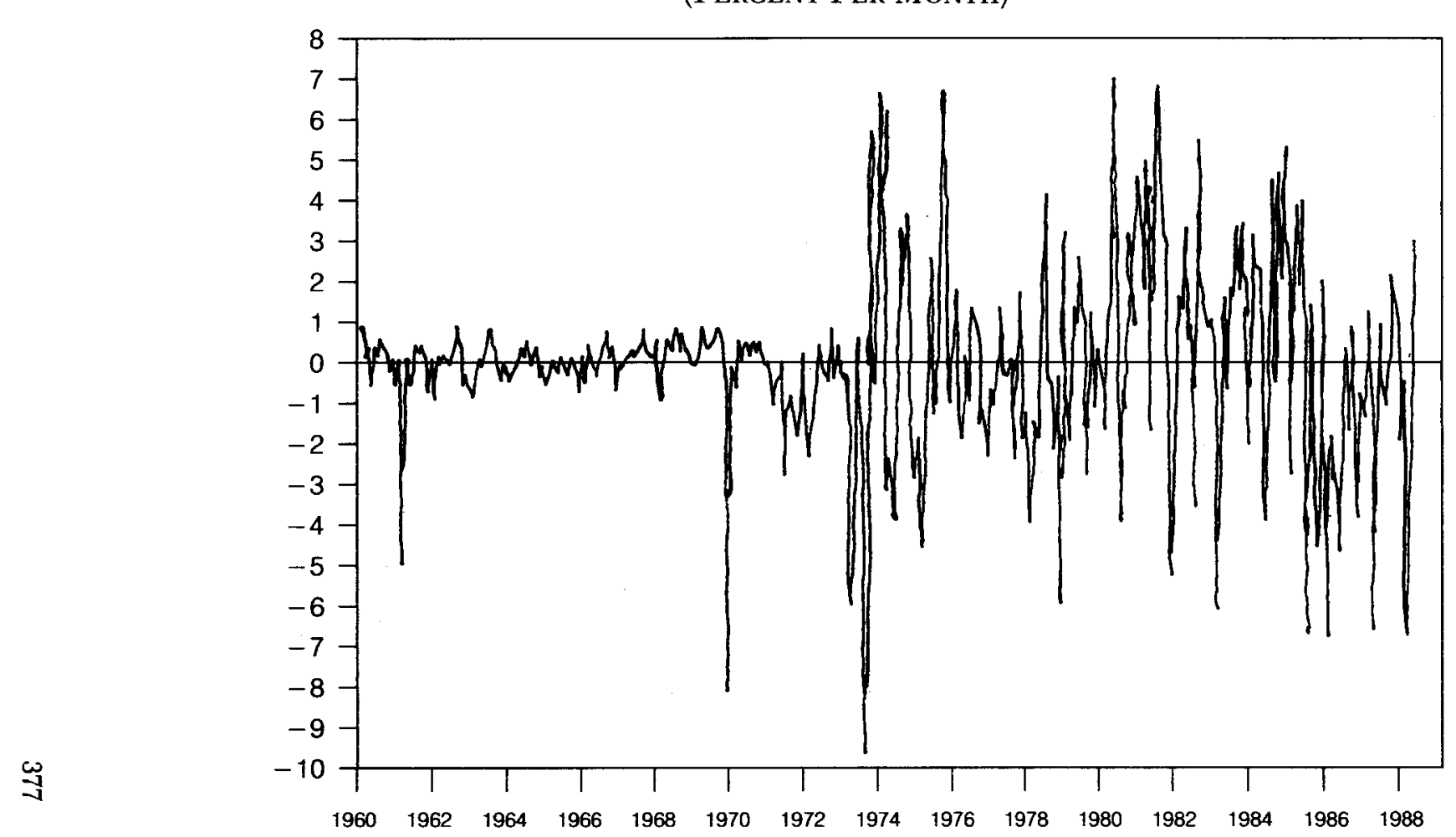




\section{Cato Journal}

regime. The evidence may not be ironclad, but the case is made with sufficient persuasion to move an open-minded jury.

McKinnon picks up this same theme. But where Mussa had shown evidence and opened up the puzzling question-why is there more volatility under flexible rates?-McKinnon injects mystical discussion of the violation of the law of one price. As is well-known, the law of one price is adduced whenever the "law," or its scientific rendition "purchasing power parity" (PPP), is found to be wanting. Paul Samuelson (1964) said the last word on purchasing power parity when he observed, "Unless very sophisticated indeed, PPP is a misleading, pretentious doctrine promising what is rare in economics, detailed numerical prediction."3

Figure 2 shows the U.S.-U.K. relative GDP deflators measured in a common currency over the past 120 years. It is apparent that the gold standard period stands out with relatively small variations in relative price levels. But it is equally clear that there are major changes in relative price levels such as after World War II or the trend in the period 1950-80. The law of one price has a bout of a problem in this longer perspective, just as it does in month-to-month fluctuations.

The interesting question is how exchange rate regimes, wage setting and pricing interact. Research on pricing under imperfect competition has started to explain the observed behavior of relative prices. Of course, the starting point of that literature is the assumption of imperfect competition, away from the "arbitrage" view that animates students of Cassel. ${ }^{4}$

There is another question that we need to understand better: Why do exchange rates move so much? The same question extends, of course, to all asset prices, whether it be real estate, stocks, or longterm bonds. The instability of asset prices may well be tied to the monetary regime, but so far no researcher has offered a plausible demonstration of that fact. The gold standard may have offered a monetary framework for regressive expectations and stabilizing expectations built around the idea of a flat trend in prices. But even then crises and crashes abounded.

\section{A New Standard?}

McKinnon has made on various occasions proposals for a new monetary regime: fixed exchange rates among the United States,

${ }^{3}$ For a detailed evaluation of PPP see Samuelson (1964) and Dornbusch (1988a).

${ }^{4}$ See Dornbusch (1988b) and Dornbusch and Giovannini (1988). 
FIGURE 2

The U.S.-U.K. Real Exchange Rate

$($ INDEX 1980 = 100)

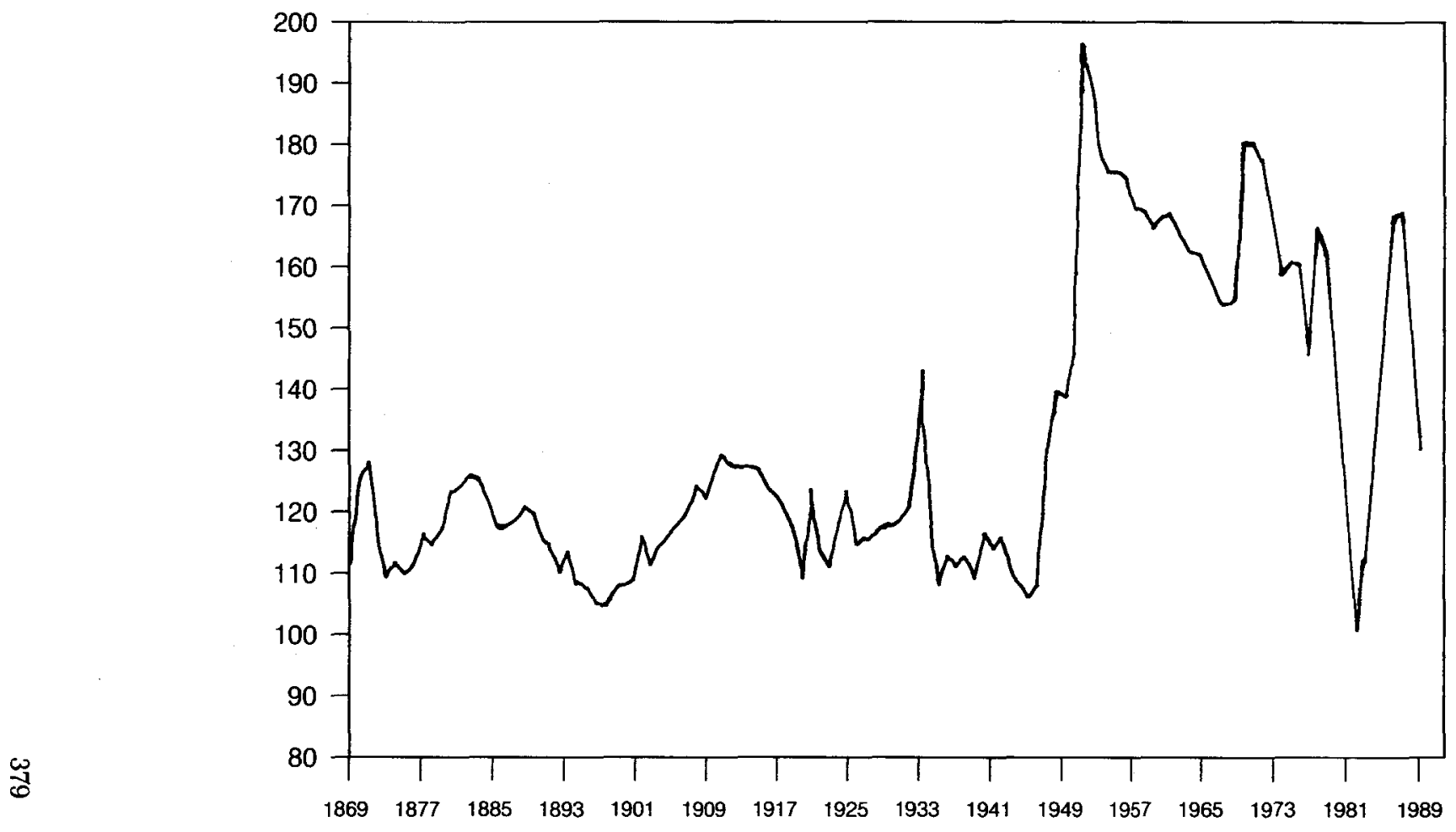




\section{Cato Journal}

Japan, and Germany combined with a world monetary rule and exchange rate-oriented domestic credit policy. In the latest versions these proposals have been accompanied by the recommendation of a sharp yen devaluation (!) to return to purchasing power parity.

I have commented elsewhere on these proposals. ${ }^{5}$ There are two major issues. First, the proposal for yen depreciation as a return to purchasing power parity leaves one baffled. The superior performance of Japan in manufacturing and trade requires real appreciation as the classical response. Precisely a move away from PPP is required as an adjustment to these favorable developments for the Japanese economy. The terms of trade improvement due to much lower real oil prices in the world economy point in the same direction.

Figure 3 shows the ratio of export prices to the GDP deflator in Japan. The downward trend reflects the Ricardo-Balassa-SamuelsonKravis effect: In countries with rapidly rising productivity real appreciation is the rule. Any crude PPP comparisons based on a "common basket of tradables" cannot possibly suggest the right level for the real exchange rate. Equilibrium real exchange rates, just as in barter theory, have to do with full employment, absorption, and intertemporal budget constraints. In that perspective real appreciation is the appropriate price response to favorable developments.

I am similarly unpersuaded by the argument that we need exchange rate-oriented monetary policy. From the work of William Poole (1970) it is known that the optimal monetary rule-targeting aggregates or interest rates-depends on the source of the disturbance. Carrying this idea over to exchange rates as intermediate targets, the McKinnon rule would be perfect if all disturbances are shifts from one country's $M_{1}$ to another's. But if we deal with portfolio shifts, then sterilized intervention is appropriate; and if they are real disturbances, then exchange rate targeting is altogether inappropriate.

The flexible exchange rate experience has left many observers unsatisfied. One alternative is a move to a far more managed system, say fixed exchange rates with rules. The common response is that there is insufficient coordination to make such a system work. Especially relying on monetary integration alone may be highly undesirable. Anna Schwartz (1986) has made a very forceful case against reviving the gold standard. Another response is to leave the system as is on the argument that there is no better arrangement, but that there is room to pursue more stable policies within a flexible rate system.

${ }^{5}$ See Dornbusch (1988b). 
FIGURE 3

Ratio of Export Prices to Deflator

$($ INDEX 1980 $=100)$

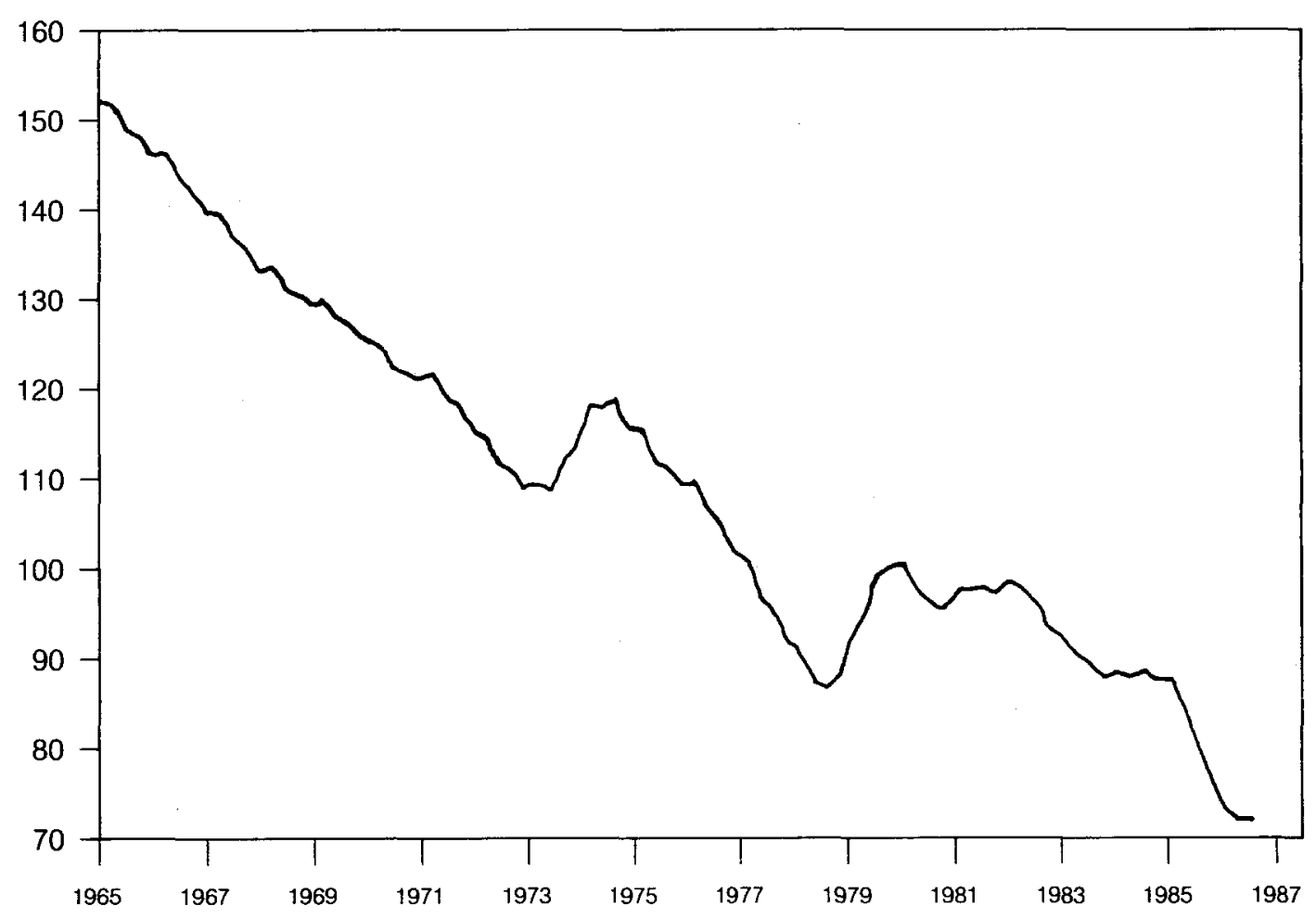




\section{Cato Journal}

A third direction is to view exchange rate instability in the broader perspective of excessively speculative markets. In that view one would argue for a very moderate financial transactions tax (on all financial transactions) so as to lengthen speculative horizons and thus encourage a predominance of long-term speculation. Of course, that was Keynes' (1936, chap. 12) answer to financial instability and it might well have found favor with Henry Simons (1948).

\section{References}

Angell, James W. The Theory of International Prices. 1926. Reprint. New York: Augustus M. Kelley, 1965.

Dornbusch, Rudiger. "Purchasing Power Parity." In The New Palgrave Dictionary of Economics. London: Macmillan, 1988a.

Dornbusch, Rudiger. "Doubts about the McKinnon Standard." Journal of Economic Perspectives 2 (Winter 1988): 105-12.

Dornbusch, Rudiger, and Giovannini, Alberto. "Money in the Open Economy." In Handbook of Monetary Economics. Edited by Frank Hahn and Benjamin Friedman. Amsterdam: North-Holland, forthcoming.

Dornbusch, Rudiger; Fischer, Stanley; and Samuelson, Paul A. "Comparative Advantage, Trade and Payments in a Ricardian Model with a Continuum of Goods." American Economic Review 67 (December 1977): 823-39.

Graham, Frank. "International Trade under Depreciated Paper: The United States, 1862-1879." Quarterly Journal of Economics 34 (1922): 220-73.

Harrod, Roy. International Economics. Cambridge: Cambridge University Press, 1934.

Hawtrey, Roy. Currency and Credit. London: Longmans, 1933.

Iversen, Carl. 1935. Reprint. Aspects of the Theory of International Capital Movements. New York: Augustus M. Kelley, 1967.

Keynes, John Maynard. The General Theory of Employment, Interest and Money. London: Macmillan, 1936.

Mints, Lloyd. A History of Banking Theory. Chicago: University of Chicago Press, 1945.

Mussa, Michael. "Nominal Exchange Rate Regimes and the Behavior of Real Exchange Rates: Evidence and Implications." Carnegie Rochester Conference Series on Public Policy 24 (1986): 117-224.

Poole, William. "Optimal Choice of Monetary Policy Instruments in a Simple Stochastic Macro Model." Quarterly Journal of Economics 84 (May 1970): 197-216.

Taussig, Frank W. International Trade. New York: Macmillan, 1928.

Samuelson, Paul A. "Theoretical Notes on Trade Problems." Review of Economics and Statistics 46 (May 1964): 145-54.

Schwartz, Anna J. "Alternative Monetary Regimes: The Gold Standard." In Alternative Monetary Regimes, pp. 44-72. Edited by Colin D. Campbell and William R. Dougan. Baltimore: Johns Hopkins University Press, 1986.

Simons, Henry. Economic Policy for a Competitive Society. Chicago: University of Chicago Press, 1948. 


\section{COMMENT ON MCKINNON}

Stockman, Alan. "Real Exchange Rates under Alternative Nominal Exchange Rate Regimes." Journal of International Money and Finance 2 (1983): $147-66$.

Viner, Jacob. Canada's Balance of International Indebtedness. Cambridge: Harvard University Press, 1924.

Viner, Jacob. Studies in the Theory of International Trade. London: George Allen \& Unwin, 1955.

Williams, John. Argentine International Trade under Inconvertible Paper Money, 1880-1900. Cambridge: Harvard University Press, 1922. 


\section{Price Level Changes and the Adjustment Process under Fixed Rates Robert E. Keleher}

The topic of Professor McKinnon's paper is considerably narrower than suggested by its title. It addresses the role of price level movements in the balance-of-payments adjustment process under fixed exchange rates. Yet it is importantly related to McKinnon's earlier proposals for international monetary reform. ${ }^{1}$ Accordingly, in commenting on McKinnon's paper, I will first indicate how it relates to his earlier proposal and why his paper is important. Second, I will discuss two specific aspects of his paper: (1) the role of price level changes in the balance-of-payments adjustment mechanism under fixed exchange rates, and (2) the assertion that price level volatility under the pre-World War I gold standard was due to global monetary instability and is not an inherent feature of fixed exchange rates.

\section{Performance of Exchange Rate Regimes and Proposals for Reform}

It is now well recognized that flexible exchange rates have not performed as many had expected. In particular:

1. Exchange rates have displayed more short-run volatility (or variability) than expected. This is the case whether exchange rates are measured in nominal or real terms, bilateral or multilateral terms. Moreover, there is little evidence to suggest that this short-run exchange rate volatility has declined as traders have become more accustomed to flexibility.

2. Exchange rates have been characterized by long-term overshooting or persistent misalignment. ${ }^{2}$

CatoJournal, Vol. 8, No. 2 (Fall 1988), Copyright $(\odot$ Cato Institute. All rights reserved. The author is Economist for the Board of Governors of the Federal Reserve System. ${ }^{1}$ See, for example, McKinnon (1984, 1988).

${ }^{2} \mathrm{Bernholz}(1982)$ indicates that such overshooting is the historical norm. 
3. Neither the short-term exchange rate volatility nor the longterm overshooting of exchange rates has been predicted; the explanatory power of existing exchange rate models has been poor.

4. Demands for international reserves have not diminished to the extent that some had expected. Governments have continued to intervene more than had been expected.

5. Economies are not as insulated and macroeconomic policies are not as independent as some had expected.

6. Trade and current account imbalances are larger in size and receive more public attention than they did under the Bretton Woods System.

7. Research suggests that relative to fixed exchange rate regimes, flexible exchange rates have been associated with much greater variability of real exchange rates and higher average levels of inflation. $^{3}$

Given this performance, it is no wonder that McKinnon and others have proposed international monetary reform. The two fundamental components of his proposal are fixed exchange rates and a monetary or price rule to serve as an anchor for the international monetary system. Since McKinnon advocates fixed exchange rates with an anchor, his proposal is not novel but essentially a variant of the classical scheme.

McKinnon's paper relates to his broader reform proposal in that he discusses both fixed exchange rates and global monetary stability. His argument is that fixed exchange rates have wrongly been identified with price level variability. In supporting this contention, McKinnon examines the pre-World War I gold standard that he views as the best example of integrated economies under fixed exchange rates. The prewar period, he points out, was associated with minimal artificial restrictions on the mobility of commodities, capital, and labor. Moreover, large net flows of capital actually occurred during the period without requiring changes in nominal exchange rates and with little variability of real exchange rates.

In examining the gold standard, McKinnon contends that while price level variability certainly did occur, it was brought about by unstable global monetary conditions and not by the functioning of fixed exchange rates. According to McKinnon, price level variability is not an inherent part of the fixed exchange rate balance-of-payments adjustment mechanism.

${ }^{3}$ See, for example, Mussa (1986), Giovannini (1987), Meltzer (1986), and Meltzer and Robinson (1987). 
McKinnon contends that this adjustment mechanism has been long misinterpreted. Specifically, the common textbook interpretation includes changes in the general price level as a fundamental element of the adjustment process. This misperception results from a common interpretation of Hume's price-specie-flow mechanism that McKinnon refers to as classical. In this view, a balance-of-payments deficit leads to an outflow of gold. The gold outflow in turn causes a contraction of the domestic money supply and hence a decline of the general price level. Deflation causes exports to become cheaper and imports relatively more expensive thereby working to reduce the trade deficit. Since the opposite happens in surplus countries, divergent movements in the general price level are commonly viewed as part of the adjustment mechanism.

The implications of this interpretation are very important. First, this view implies that fixed exchange rates necessarily are associated with price level variability (or volatility) and not price level stability. Such price level variability is seen as an inherent element of fixed exchange rates. Second, this view has led some well-known monetary writers to contend that the choice between fixed and flexible exchange rates is the choice between exchange rate stability and price stability.

McKinnon, contends that this interpretation of the adjustment process is incorrect and misleading. Divergent movements of general prices are not part of the adjustment mechanism of an open economy under fixed exchange rates in an integrated world. In such circumstances there is a common price level (for tradable goods) maintained by active arbitrage. Divergent price level movements would violate the law of one price and purchasing power parity. Instead of divergent price level movements, adjustment occurs via flows of goods and capital. Accordingly, the choice between fixed and flexible exchange rates is not a choice between stable exchange rates and stable prices.

\section{The Classical Position}

I believe McKinnon is correct on this commonly misunderstood point. Before examining the empirical evidence, however, it is important to mention that McKinnon fosters the common misperception that the divergent price level view of the adjustment process was endorsed by classical monetary writers. He refers to the view that price levels do not diverge as "revisionist." I believe these labels are misleading and incorrect.

A careful reading of original classical monetary writers leaves little doubt that these writers did not support the divergent price level 
view. ${ }^{4}$ These writers all endorsed the natural distribution of specie hypothesis and the law of one price. Moreover, they explicitly stated that divergent movements of general price levels (or prices of tradable goods) were not part of the adjustment mechanism under fixed exchange rates. Divergent price level movements were not possible because of the constraints of arbitrage.

This nonprice-diverging view applies to David Hume as well as to Adam Smith and the Bullionist writers. Banking School writers, John Stuart Mill, Knut Wicksell, and J. Laurence Laughlin also held this interpretation. This view, therefore, was the orthodox view from Hume until the early 20th century when it fell into eclipse for a number of reasons. ${ }^{5}$ In fact, empirical evidence was provided by John Wheatley, Thomas Tooke, John Cairnes, and Laughlin to show that divergent price level adjustments never received factual support. In short, the interpretation that classical monetary writers endorsed a divergent price level adjustment mechanism is incorrect. The view supported by McKinnon and those writers adopting the modern monetary approach to the balance of payments is classical, not revisionist.

\section{The Pre-World War I Evidence}

To support his contentions, McKinnon examines the pre-World War I gold standard. The prewar case is appropriate since it is an example where exchange rates were fixed, economies were well integrated, and minimal tariffs, capital controls, and immigration restrictions existed. McKinnon contends that common misinterpretations of the operation of fixed exchange rates is epitomized by interpretations of this period. More specifically, he contends that while it is common to attribute the period's price level volatility to fixed exchange rates, the operation of fixed exchange rates has not been sufficiently distinguished from the period's global monetary and price instability. While the period is characterized by price level variability, this was due to unstable world monetary conditions rather than to fixed exchange rates.

As evidence to support his view, McKinnon cites the work of Richard Cooper (1982) and Robert Triffin, which suggests that price levels of various countries moved together during the prewar period rather than diverging. Furthermore, McKinnon cites evidence from McCloskey and Zecher as well as from Dick and Floyd that show parallel, not divergent, movement in the prices of tradable goods.

${ }^{4}$ See Keleher (1978), Humphrey and Keleher (1982), and Glasner (1985).

${ }^{5}$ See Humphrey and Keleher (1982, pp. 200-202) for a discussion of these reasons. 
While this evidence does suggest that prices move together rather than diverging, McKinnon has not produced empirical evidence to support his contention that unstable global monetary conditions produced short-term price level variability. Some evidence (Bordo 1981, Cooper 1982, Meltzer 1986, Meltzer and Robinson 1987) does indicate that short-term price variability was higher during the gold standard years. But other evidence (Bernholz 1983) suggests that such variability may not have been the case for all countries. ${ }^{6}$ Moreover, part of the reason for the short-term price variability may have been due to the domination of agricultural prices in the periods' wholesale price indices and hence related to agricultural instability rather than global monetary instability. ${ }^{7}$ The method of measuring variability in one of these studies is also open to question. ${ }^{8}$

In contending that global monetary conditions were unstable, McKinnon points out that the gold base became smaller during the 1885-1913 period. While this may increase the vulnerability of the system to shocks, it does not necessarily imply anything about actual price variability or volatility. Moreover, while gold production increased sharply from about 1890 to World War I, this in itself does not imply anything about short-term price variability. Yet, as Michael Bordo (1986) has shown, financial crises including stock market crashes and bank runs occurred nearly simultaneously in numerous countries during the prewar period, which seems to support McKinnon's position.

Finally, if the period did experience global monetary instability as McKinnon suggests, he should indicate how such short-term price variability is reconciled with the well-documented long-run price stability found by several researchers. It is difficult to believe that this stability is accidental as McKinnon seems to suggest. ${ }^{9}$

\footnotetext{
${ }^{6}$ Bernholz (1983) found that the variance of price movements during the gold standard period was higher only for the United States and Germany but not for France and England. Similarly, Cooper (1982) indicated that in England, the standard deviation of price change was lower during the gold standard period than in the postwar period. Moreover, Meltzer (1986) indicated that the variance of the price level was lower under the gold standard than under the recent fluctuating exchange rate regime: "The variance of the price level increased under pegged interest rates, but it is highest in the recent period of fluctuating exchange rates and relatively high inflation" (p. 139).

${ }^{7}$ Notably, recent research by Romer $(1985,1986)$ and Sheffrin (1988) has shown that economic fluctuations were not more severe under the gold standard as compared to more recent experience.

${ }^{8}$ The measurement of price variability used by Meltzer has been questioned by Carl Christ (1986).

${ }^{9}$ Most interpreters of the classical gold standard contend that fixing the price of gold creates incentives for the working of a self-regulating mechanism that ensures longrun price stability. See, for example, Aliber (1982, pp. 152-53).
} 


\section{Cato Journal}

In sum, while McKinnon's assertions about the adjustment mechanism under fixed exchange rates seem well founded, one has to remain skeptical of his contention concerning global monetary instability. Indeed, such skepticism must persist until McKinnon provides us with more empirical evidence to support his claim and until he reconciles short-run global instability with long-run, secular price stability.

\section{Regional Price Evidence}

In order to assess the working of an unhampered fixed exchange rate system, the examination of the pre-World War I period is certainly appropriate. It is, after all, a period when economies were integrated, exchange rates were fixed, and artificial barriers to the movement of commodities, capital, and labor were minimal. But another, perhaps even better, example exists that should be mentioned. In particular, the set of regions within the U.S. economy satisfy all of these characteristics. Specifically, these regions are well integrated and effectively function as if in a common currency area (i.e., as if immutably fixed exchange rates existed). No tariffs or capital controls exist and since factor mobility is prevalent, there is an automaticity in the balance-of-payment adjustment process. Finally, some relatively consistent and reliable data is available to assess the working of these regions.

If regional price data are examined, the following conclusions seem readily apparent:

1. There is no evidence of divergent price level movements as part of a balance-of-payments adjustment process. There is a common price level.

2. Tradable good prices move together and do not diverge.

3. The only prices that differ significantly are nontradable prices of such goods as housing, rent, labor services, and so forth.

4. Adjustments to balance-of-payments disturbances between regions have apparently taken place smoothly despite common views as to the severity of such adjustments under fixed exchange rates. Apparently, the transfer problem works as McKinnon suggests; that is, it does not necessarily require price level adjustments.

5. Finally, if price levels are variable, it is because the price level in the United States as a whole is variable.

In short, the regional price evidence seems to support McKinnon's (or the classical) view of the balance-of-payment adjustment process under fixed exchange rates. 


\section{Conclusion}

There is both contemporary and historical theoretical precedent as well as empirical evidence to support McKinnon's classical view that divergent price level movements are not part of the adjustment process under fixed exchange rates. However, one must remain skeptical of McKinnon's contention about global monetary and price instability during the pre-World War I period until he provides more convincing evidence to support his assertions.

McKinnon's assessment is appropriate for circumstances where exchange rates are immutably fixed and there exists little expectation that government will alter the exchange rate or manipulate it as a policy tool. Unfortunately, these circumstances do not exist today and it is unlikely that they will in the near future. Nonetheless, McKinnon's paper suggests that in considering proposals for reform as well as in properly comparing fixed versus flexible exchange rates, economists ought at least to understand how fixed exchange rates worked.

\section{References}

Aliber, Robert Z. "Inflationary Expectations and the Price of Gold." In The Gold Problem: Economic Perspectives. Edited by Alberto Quadrio-Cruzio. New York: Oxford University Press, 1982.

Bernholz, Peter. Flexible Exchange Rates in Historical Perspective. Princeton Studies in International Finance, no. 49. Princeton, N.J., July 1982.

Bernholz, Peter, "Inflation and Monetary Constitutions in Historical Perspective." Kyklos 36 (1983): 397-419.

Bordo, Michael D. "Financial Crises, Banking Crises, Stock Market Crashes, and the Money Supply: Some International Evidence, 1870-1933." In Financial Crises and the World Banking System. Edited by Forrest Capie and Geoffrey E. Wood. London: Macmillan, 1986.

Bordo, Michael D. “The Classical Gold Standard: Some Lesson for Today." Federal Reserve Bank of St. Louis Review 63 (May 1981): 2-17.

Christ, Carl F. "Accuracy of Forecasting as a Measure of Economic Uncertainty." In Alternative Monetary Regimes, pp. 154-60. Edited by Colin D. Campbell and William R. Dougan. Baltimore: Johns Hopkins University Press, 1986.

Cooper, Richard N. "The Gold Standard: Historical Facts and Future Prospect." Brookings Papers on Economic Activity 1 (1982): 1-56.

Giovannini, Alberto. "Prices and Exchange Rates: What Theory Needs to Explain." Paper prepared for the 1987 ASSA Meetings, Chicago, Ill., December 1987.

Glasner, David. "A Reinterpretation of Classical Monetary Theory." Southern Economic Journal 51 (July 1985): 46-67. 


\section{Cato Journal}

Humphrey, Thomas M., and Robert E. Keleher. The Monetary Approach to the Balance of Payments, Exchange Rates, and World Inflation. New York: Praeger, 1982.

Keleher, Robert E. "A Framework for Examining the Small, Open Regional Economy: An Application of the Macroeconomics of Open Systems." Working Paper Series, Federal Reserve Bank of Atlanta, December 1977.

Keleher, Robert E. "Of Money and Prices: Some Historical Perspectives." In The Monetary Approach to International Adjustment. Edited by Bluford Putnam and Sykes Wilford. New York: Praeger, 1978.

McKinnon, Ronald I. An International Standard for Monetary Stabilization. Washington, D.C.: Institute for International Economics, 1984.

McKinnon, Ronald I. "Monetary and Exchange Rate Policies for International Financial Stability: A Proposal." Journal of Economic Perspectives 2 (Winter 1988): 83-103.

Meltzer, Alan H. "Some Evidence on the Comparative Uncertainty Experienced under Different Monetary Regimes." In Alternative Monetary Regimes, pp. 122-53. Edited by Colin D. Campbell and William R. Dougan. Baltimore: John Hopkins University Press, 1986.

Meltzer, Alan H., and Saranna Robinson. "Stability under the Gold Standard in Practice." Working Paper, Carnegie-Mellon University, September 1987.

Mussa, Michael L. "The Exchange Rate Regime and the Real Exchange Rate." Paper presented at American Economic Association Meetings, New Orleans, December 1986.

Romer, Christina. "Is the Stabilization of the Postwar Economy a Figment of the Data?" American Economic Review 76 (June 1986): 314-34.

Romer, Christina, "The Prewar Business Cycle Reconsidered: New Estimates of Gross National Product, 1872-1918." Working Paper, Princeton University, 1985 .

Sheffrin, Steven M. "Have Economic Fluctuations Been Dampened?" Journal of Monetary Economics 21 (1988): 73-83. 